\title{
The state of the art in comparative education and WCCES at a crossroads in the 21st Century
}

\author{
Carlos Alberto Torres
}

\begin{abstract}
:
The focus of this work is the potential contributions and emerging challenges in comparative education. Globalization has brought a heterogeneous world globalization, having the global capitalism mostly as an expression, whereas there has been place enough for dissent. Limited theory and empirical research defeat the purpose of comparative education as an intellectual field for the analysis of globalization and antiglobalization. The author, based on the journey of a critical theorist as WCCES president, establishes a brief historical perspective of comparative and international education. Regarding the latter not as a discipline, but as an interdisciplinary field, he states that in this period we learned to work in three broad orientations: scientific, pragmatic and an international dimension of education, eminently global. However, the best contributions of comparative and international education have not taken place in WCCES. Therefore, this work concludes with proposals for the Council. The most important are the adoption of the positions of the Incheon Meeting, as well as to assume that our commitment remains firm in favour of equity transformational projects.
\end{abstract}

Key words:

comparative and international education; critical theory; globalization; global capitalism; WCCES. 


\title{
L'état de l'art de l'Éducation comparée et le Conseil mondial des sociétés d'éducation comparée au carrefour du XXle siècle.
}

\begin{abstract}
Résumé: Ce travail analyse les contributions potentielles et les défis émergents de l'Éducation comparée. La mondialisation a modelé un processus hétérogène ayant le capitalisme global pour expression. En même temps, il ouvre un espace pour les divergences. La théorie et la recherche de terrain limitée constituent un obstacle au but de l'Éducation comparée en vue de s'affirmer comme un domaine intellectuel pour l'analyse de la mondialisation et de l'antimondialisation. L'auteur, se basant sur sa carrière de théoricien critique et sur son expérience en tant que Président du Conseil précité, dresse une brève perspective historique de l'Éducation comparée et internationale. Considérant cette dernière non pas comme une discipline mais plutôt comme un domaine interdisciplinaire, il soutient que nous apprenons actuellement à travailler à l'aide de trois grandes orientations: la scientifique, la pragmatique et la dimension internationale de l'éducation, éminemment mondiale. Toutefois, les meilleures contributions de l'Éducation comparée et internationale n'ont pas encore émergées au sein du Conseil. Partant, ce travail conclut par des propositions pour la continuité de cette tâche. Les plus importantes passent par l'adoption des positions de la Conférence d'Incheon, et par la réaffirmation d'un ferme engagement à oeuvrer dans le sens de projets d'égalité et de transformations.
\end{abstract}

Mots clés: éducation comparée et internationale; théorie critique; mondialisation; capitalisme global; conseil mondial des sociétés d'éducation comparée.

\section{El estado del arte de la educación comparada e el consejo mundial de las sociedades de educación comparada en sus dilemas del siglo XXI}

Resumen: El foco de este trabajo es el de las potenciales contribuciones y desafíos emergentes de la educación comparada. La globalización modeló una globalización heterogénea del mundo, cuya mayor expresión es el capitalismo global, mientras hay local suficiente para la disensión. Limitadas teorías e investigaciones son obstáculos al propósito de la Education comparada como campo intelectual para el análisis de la globalización y la anti-globalización. El autor, basado en su carrera de teórico crítico y presidente del Consejo Mundial de las Sociedades de Educación Comparada, diseña una breve perspectiva histórica de la educación comparada e internacional. Considerando esta no como una disciplina, pero como un área interdisciplinaria, afirma que en este periodo hemos aprendido tres amplias orientaciones: científica, pragmática y una dimensión internacional de la educación, eminentemente global. Sin embargo, las mejores contribuciones no florecieron en el Consejo. Así, este trabajo concluye con proposiciones para este órgano. Las más importantes son la adopción de las posiciones de la Conferencia de Incheon y asumir que nuestro firme compromiso se queda con proyectos de igualdad y transformación.

Palabras clave: educación comparada e internacional; teoría crítica; globalización; capitalismo global; consejo mundial de las sociedades de educación comparada.

\section{O estado da arte da educação comparada e o conselho mundial das sociedades de educação comparada em suas encruzilhadas do século XXI.}

Resumo: $O$ foco deste trabalho situa-se nas potenciais contribuições e desafios emergentes da educação comparada. A globalização trouxe uma globalização heterogênea do mundo, tendo como maior expressão o capitalismo mundial, deixando espaço aberto para as divergências. Teoria e pesquisa de campo limitadas constituem obstáculo ao propósito da educação comparada como campo intelectual para a análise da globalização e da antiglobalização. O autor, baseado em sua carreira de teórico crítico e sua experiência como presidente do referido Conselho, desenha uma breve perspectiva histórica da educação comparada e internacional. Considerando esta última não como disciplina e, sim, uma área interdisciplinar, afirma que, neste período, aprendemos a trabalhar com três amplas orientações: científica, pragmática e uma dimensão internacional da educação, eminentemente global. Todavia, as melhores contribuições da educação comparada e internacional não floresceram no Conselho. Assim, o trabalho conclui com proposições para a continuidade da sua trajetória. As mais importantes são a adoção das posições da Conferência de Incheon, bem como assumir que nosso firme compromisso se mantém com projetos de igualdade e transformações.

Palavras-chave: educação comparada e internacional; teoria crítica; globalização; capitalismo global; conselho mundial das sociedades de educação comparada. 


\section{Liminar}

Comparative education was born in the twilight of the nineteen-century and became consolidated as an academic discipline in the $20^{\text {th }}$ century. Yet, throughout the $20^{\text {th }}$ century, it was a relatively marginal, obscure and unconventional discipline that acquired new luster and relevance with the onset of globalization".

This keynote will offer an analysis of what are the potential contributions and emerging challenges of comparative education. This state of the art of the discipline will confront the potential roles of the WCCES to address these challenges in a increasingly interdependent world and in the context of a more complex institutional and diverse professional setting.

\section{From globalization to comparative education}

Comparative and international education is a field in perpetual transformation. Multiple globalizations have had a heavy impact in the field and its orientation. I have written about the different faces of globalization. Globalization takes different forms and we really should talk about globalization processes in the plural, because there are multiple globalizations with multiple faces.

Here we would like to call attention to the predominant forms of globalization. One form, often seen as 'globalization from above', is framed by an ideology of neoliberalism and calls for an opening of borders, the creation of multiple regional markets, the proliferation of fast-paced economic and financial exchanges, and the presence of governing systems other than nation-states. Without any doubt, the dominant form of neoliberal globalization has affected 'competition-based reforms' transforming educational policy in $\mathrm{K}-12$ and higher education.

Another form represents the antithesis of the first. This form of globalization is often described as 'globalization from below', or anti-globalization. Globalization from below is largely manifested in individuals, institutions and social movements actively opposed to that which is perceived as corporate globalization. For these individuals and groups, 'no globalization without representation' is the motto. There is a third form of globalization, which pertains more to rights than to markets - the globalization of human rights. There is a fourth manifestation of globalization. This form extends beyond markets, and to some extent is against human rights. It is globalization of the international war against terrorism.

There is a fifth form of globalization that is the growing hybridity that crisscrosses the world. There is a sixth form of globalization: The Global Media. There is finally another form of globalization connected with the principles of the knowledge society, and the network society 
All of this forms of globalization are deeply affecting our discipline. Not surprisingly comparative international education is experiencing what could be perceived as an identity crisis. What is really comparative international education? A field of expertise with a scientific comparative method like the one that some of our predecessors from the early decades tried to establish from a positivist orientation? A field concerned with the practical implications of the loaning and borrowing of innovations among educational systems? A field concerned with the internationalization of education and the implications of global education for world citizenry? Or are all of the above, the famous line in many survey instruments? I will address some of these issues below in this keynote.

The field has evolved from its precarious beginnings and by most standards has progressed internationally with a reasonable degree of academic institutionalization and respectability. Despite progress, perpetual questions about identity continue to besiege the field and many of its practitioners. If I may read this situation through the lenses of Marx, many discussions in comparative education show "the poverty of theory" in the field.

Debates on theory and method in comparative education, rather than showcasing the new progress in theory and methods, ultimately underscore the need for a better intellectual definition of the field and, particularly, for what could be termed as better ways of teaching, research and policymaking in the trade but also as the art of comparative international education.

Globalizations will not provide us with answers for these questions. Instead, globalization highlights and indeed challenges the field to answer the question of what is the relative advantage of comparative education in understanding the changing social context of education, and some of the secular dilemmas of equity, equality, and quality of education throughout the world? Is there a renewed importance of comparative and international education as a field of scholarship and inquiry with the increasing interconnectedness of all societies? This in no way implies that globalization has brought to us a more homogeneous world; the opposite could also be true in several domains. In short, if globalization is mostly an expression of global capitalism ruling the world, there is enough room for dissent. Moreover, there is a diasporic process of people's movements and cultural renewal that cannot be easily coerced into a neoliberal one-size-fitsall lifestyle, particularly when neoliberal globalization, rather than incorporating the majority of the population of the world on equal terms, marginalizes and impoverishes it.

If one were a provocateur, one might ask, is comparative education as a field ready to leave that unconscious and cozy niche of being a residual category in scholarship that incorporates scholars and technocrats coming from several disciplines with an international and comparative orientation? Is comparative education no longer simply a reflection of people that might not have found a better professional, academic, or 
institutional niche elsewhere (or were not good enough to do so in disciplinary camps, particularly in the early period)? Yet as I have said in my book entitled Education, Power and Personal Biographies that if we scratch a theory we find a biography. The biographies of our predecessors made comparative education an established profession, discipline, and field. There is no question that comparative educators as well as most critical education perspectives were aided by the economic boom of the 1950s and 1960s, and the ensuing economic stability and academic institutionalization of capitalist advanced societies. These consideration, coupled with continued in knowledge construction, rather than sheer excellence, helped to get the field to what it is now.

No matter how uncomfortable they might be, questions of equality, equity and quality of education are perennial challenges for comparative education because questions of identity will never go away. We should remain oriented and sensible to the new historical realities of its time.

Interdisciplinarity in education and social sciences has reached a level never seen before. The contributions of comparative and international education appear as a precondition for any rigorous analysis of democracy, citizenship, and multiculturalism, just to cite three classic themes that should be part not only of our theoretical and methodological toolbox, but of our own individual passions if we want a better, more caring, more just and ethical and sustainable development world.

What seems to be new today is that globalization has catapulted the concern for the international and comparative dimensions in education, in most areas of expertise, well beyond the wildest imagination of comparative education scholars, advocates, and practitioners. Yet, this awareness comes at a price. The effort to know what the multiple globalizations are, what are its origins and its implications for education, just to speak about our field, reveals a multitude of answers, approaches, and analyses. However, this effort for understanding hitherto lacks concrete empirical and comparative international research products. In an academic world where there is less and less money for research, this is worrisome.

So we have come full circle. Limited theory and limited empirical research defeats the purpose of comparative education as an intellectual field for the analysis of globalization and anti-globalization movements. More so if it ignores the movements for global social justice and equality. While globalization is heralded by neoliberalism as a new model of social relationships throughout the world, not all the regions in the world, or localities in all countries, are being globalized in the same manner, intensity, and direction. Furthermore, some regions (and some educational systems) are not being globalized at all.

But of course, the answer to the implications of globalization and anti-globalization movements always depends on the framework that we use to analyze them. I can imagine that an expert of the World Bank or OECD, and a poor yet politicized peasant 
of the Movimento dos Sem Terra (Landless Peasant Movement) in Brazil, may view globalization processes with different lenses and having radically different expectations.

It is true that the macro-narratives have been damaged by the postmodernist storm and, according to some, are beyond repair. However, to accept that reality is simply a social construction, and that every social construction is as good as the next one, or that all we are, do, and struggle for, are simply constructed narratives marinated in the linguistic turn could be seen as if we, scholars in comparative education have accepted the defeat of Reason.

Multiple globalizations bring with its baggage not only a new challenge and a crisis for comparative education as a field. The debate about globalization and the presence of anti-globalization movements present us with new opportunities to conduct serious cross-cultural and comparative investigations about globalization in education and sharpen our methodologies and theories.

In facing these challenges will we be able to provide a better answer to our perpetual question of who are we, and what our contributions can be, the differentia specifica so to speak, in scholarship that comparative educators provide to better the world? I am afraid it is not only a matter of learning the trade of research and teaching skills. A consistent answer to these questions requires, above all, vision, wisdom, generosity, and compassion.

\section{The journey of a critical theorist as president of WCCES}

I would like to talk to you today as President of WCCES having been elected democratically by $2 / 3$ of the societies of comparative education in July 2013 in the XV World Congress of Comparative Education Societies in Buenos Aires Argentina, my native city. It is a great honor to have served as President, and in this keynote, I would like to share with you some of my learnings in the WCCES as well as over 40 years of working in education in diverse capacities. This message is also about my legacy but, far more importantly, about the future of comparative and international education and the WCCES.

While investigating the state of WCCES I travelled extensively, perhaps more than any president has ever travelled visiting societies, members of comparative education societies and occasionally providing keynotes in annual meetings. I travelled mostly with my own funds provided by UCLA rather than using the limited funds of WCCES.

I visited 17 societies in six continents in my tenure. My travel as President and as scholar are equivalent to many trips around the world, considering that one round trip around the circumference of the Earth is equivalent to 24901.55 miles or if one counts that planet Earth is an oblate spheroid, this means that the Earth is flattened along the axis from pole to pole, such that there is a bulge around the equator. This bulge results from the rotation of Earth, and causes the diameter at the equator to be 43 kilometers 
(27 mi) larger than the pole-to-pole diameter. So depending on where I traveled from, I would have traversed a different amount of miles, which is between 24.90155 to 27,000 miles.

There was another source of learning working with the Executive Committee and with the Bureau, and understanding the growing pains that my changes in the institutionalization and professionalization of WCCES provoked. The resolution of conflicts opens incredible perspectives and stimulates creative imagination.

I speak also from a whole life devoted to working in comparative education, having joined CIES in 1980 as a graduate student at Stanford University, becoming President of CIES in the mid-nineties, 10 years after my graduation with my Ph.D.

However, I have not restricted my work to comparative and international education, but I shared my academic work with other theoretical and empirical fields such as the political sociology of education that I helped to formulate in the 1980s, the studies on Paulo Freire's Critical pedagogy, Critical Theory à la Frankfurt in education, and my work on multiculturalism, globalization, neoliberalism's new common sense and education in Latin America.

I speak also as Distinguished Professor of Education and Unesco UCLA Chair in Global Learning and Global Citizenship Education. It is a great honor to be the holder of the first Unesco Chair ever accepted by the University of California System in its history. It is because the generosity of the tax payers of California that I had access in each year of my administration to close of $\$ 125,000$ dollars of institutional contributions from UCLA, which facilitated my dedication to the job of President while teaching and conducting research at UCLA. This funding contributed to the salary of my Assistant to the President, now Dr. Jason Dorio, whom you must have met for the many messages he has circulated in the last 3 years on my behalf.

I speak as a prolific author in my fields of expertise. Specifically in our field, I have the honor to publish with Robert Arnove as editors Comparative Education: The Dialectic of the Global and the Local, now with Steven Franz in its fourth edition with translations in Spanish, Portuguese, Chinese, and other languages. This book, as indicated by the theme of this World Congress, is a reference in the discipline.

I speak also as a public intellectual intimately linked to the Critical Theory of Society, in the spirit of the Frankfurt School, and Critical Pedagogy, in the spirit of Paulo Freire. I imagine that the societies that have chosen me to preside over WCCES knew that in the administration of this Council, as a Critical Theorist I will apply the principles of theories built in the struggles for liberation.

Perhaps those who have read my work understand that as Critical Theorist we cannot separate the analytical from the normative. Therefore, academics in these traditions cannot be voyeurs observing reality with sarcasm and irony while enjoying their own privileges, or technocrats who implacably implement their models of social engineering 
without considering the damage that they can do to countries, communities and individuals.

Let me say that for critical theorists of society, the contradiction of reality hurt us very intimately, and that this is the reason we teach, conduct research and accept responsibilities in administration to change the world for the better, not to reproduce it. From this institutional platform and from my own voice I want to offer a short historical perspective of comparative and international education and then to discuss the role and responsibilities of the Council of Comparative Education Societies for the future.

\section{Comparative and international education: a brief historical perspective}

Our positivist predecessors were obsessed with the goal to develop the comparative method, and the application of laws and generalizations to understand education. Though this obsession was useful to establish the discipline and to institutionalize courses in universities, most of them failed to link this emerging field with discussions about social foundations of education especially in the first quarter of the last century that saw the contributions of John Dewey, who is not well represented among the founders of the discipline.

Dewey spent a number of years studying and participating in educational transformations of magnitude. In his long and productive academic career, he studied and/or visited educational transformations in revolutionary Mexico, the first social revolution of the twentieth century, and the revolutions in the Soviet Union and China, among others processes of social transformation.

In my beloved Latin America, I shall note that there still has not been made a systematic study of the contributions of Domingo Faustino Sarmiento who, already in the first half of the nineteenth century had developed contributions that could well qualify him as one of the precursors of comparative and international education in the entire world.

Sarmiento was a man as genial as controversial. With the publication of Facundo in 1845, Sarmiento inaugurated a controversial but important literary tradition that I dare say is foundational not only of gauchoesque literature (reflecting the mentality of the gaucho, an equivalent to the American cowboy) that comes partly in response to his argument about the tensions between civilization or barbarism but of Argentinean literature as such.

Sarmiento was an exiled and inveterate traveler who traveled and learned from others, activities that once the Greeks defined as the role of the philosopher. The one who travels and learns represents the essence of philosophy.

Between 1845 and 1848 Sarmiento visited Europe -in the middle of the social revolutions that Marx studied in the 18 Brumaire of Napoleon Bonaparte, and visited the United States, where he travelled to 21 states, and discovered, in Boston, Horace Mann, then Superintendent of Public Instruction of the State of Massachusetts. It was 
Horace Mann who offered to Sarmiento the principles of the model of public education he was searching for Sarmiento, who eventually became $7^{\text {th }}$ President of Argentina, was a self-made man, an autodidact who was searching for the proper model of education for the emerging new nation-state of post-colonial Argentina.

Sarmiento visited the United States again in 1865 as Minister Plenipotentiary and Extraordinary Ambassador to the US coinciding with the end of the Civil War and Lincoln's assassination. He learned in the United States that slavery was an atrocity that needed to be eliminated from the Earth, and that gender equality was indispensable to achieve through education for citizenship building. He invited a large number of women teachers to come to Argentine to teach, despite of the fact that they were all Protestant and most likely would not be well received in the nascent Catholic country. Sarmiento's political and pedagogical travels is that they were in the eye of the social and political storm of his time.

When Sarmiento published the fruits of his in trips in a book entitled Popular Education in 1849 and invented public education in Latin America became a unwillingly a practitioner of a nonexistent discipline: international comparative education.

For Sarmiento public education is the ideal path to educate citizens who will build the nation-state. In Popular Education (1849), Sarmiento writes that the adoption of a policy of equality is "the basis of social organization". Moreover as has been noted by several commentators, Sarmiento along the lines of the democratic revolutions of the XIX century states that it is "the duty of every government to provide education to future generations because we cannot compel all individuals in the present generation to receive the intellectual preparation which involves the exercise of the rights that are attributed to citizenship."

Having suffered and observed the hegemonic anti-intellectual moment in his country unequivocally, he stated that "not educating a new generations, all the flaws that our current organization suffers will continue to exist" ( p. 26). (Domingo Sarmiento, 2010)

Ricardo Piglia, in a beautiful text entitled Notes on Facundo, canonized Sarmiento as one of the early pioneer intellectuals in comparative education. For Sarmiento, "to know it is to compare. Everything makes sense if it is possible to reconstruct the analogies between what you want to explain and something else that is already judged and writen" (p. 17). (Domingo Sarmiento, 2010)

Forgive me for this apparent analytical digression mentioning Sarmiento but it seemed relevant at a meeting of specialists in international comparative education more so when a great deal of the history of comparative education has been told from the perspective of the global North, not the global South.

A second stage, say about fifty to sixty five years ago, comparative education grows accompanying the new vision that proposes a relatively new discipline of economics of education. It is the economics of education that sees education not as an expenditure but as an investment that pays off extensively in the formation of human capital. 
This view coincides with the optimism of having defeated Nazism and the new democratic perspectives that would reign in advanced democracies of the world system radically expanding educational opportunities, access and funding that massively impact much of the world system. Unesco emerges as an institution to galvanize democracy and human rights, and to promote the key components of education and culture. Not surprisingly, many students of comparative education found jobs in Unesco.

This generation of comparativists developed in the context of the early stages of the Cold War at the end of World War II. So many of these contributions are marked by the struggle between the Western capitalist world led by the US and the Soviet bloc countries with their allegiance to a communist project. There was a in a bid to confront communism in the Third World, especially considering the process of decolonization of Asia, Africa and Oceania.

Because knowledge is not unidirectional, there were however important influences from the Third World in these discussions, particularly what later came to be known as the epistemology of the global South. For instance the political and pedagogical work of Ho Chi Minh, with his sobering statements for instance: "Remember, the storm is a good opportunity for the pine and the cypress to show their strength and their stability." Confronting the Pedagogy of the Oppressed, the contributions of Paulo Freire (2005) became universal. The work of Julius Nyerere from Tanzania, one of Africa's most celebrated figures, who was a politician of great intelligence and even more solid principles inspired generations of scholars including us in Argentina very attentive to the process of post-colonialism in Africa. He was known as Mwalimu or teacher who has a vision of education as the logic of possibility.

Africa gave us iconic figures of education and social liberation such as Nelson Mandela and Amílcar Cabral. Mandela who spent more than two decades imprisoned as a 'terrorist' upon his liberation was the architect of reconciliation in South Africa, or Amílcar Cabral whose book the The Weapon of Theory (2010) influenced my whole generation of activists and educators in Argentina.

The names of Evita, one of the most noted fighters for women equality in Latin America, or Rosita Weinschebaum Ziperovich come to mind. Rosita Ziperovich worked as a rural teacher and trade union militant for more than 70 years. She was fired many times from her work as teacher and administrator; either because she was a socialist, or did not agree with the Peronist government or simply because she was a Jew. At 81 years of age, in 1994, despite her failing health, she worked as Federal Representative in the Reform of the Argentinean Constitution with special interest in the changes in education law.

The list of people who have contributed to the educational adventure is very long. Particularly of people who fought for social transformation and were assassinated by the true forces of terror, state terrorism. As an Argentinean exiled from one of the most murderous dictatorships in the region I want to honor the names of the invisible educators murdered 
for their convictions or their pedagogical practice. The invisible teacher that works in the trenches in the most remote and most dangerous places of the Earth, and who could not even dream to come to a Congress like this one to engage in critical discussions about education. They are making this world a better place and their students better citizens.

In addition to extraordinary leaders, the Third World offered educational systems that were beginning to show signs of autonomy constituting mass national education systems at unprecedented levels. The convergence or institutional isomorphism in organizational terms led to several analysts, especially those linked to neo - institutionalism to talk about a global culture.

In the utopian spirit of the sixties another generation of comparativists emerged seeking to create an alternative vision of education. This implied a criticism of the positivist tradition of discipline. It also meant rethinking the dimensions of this discipline encompassing humanities, social sciences, area studies, multiple methodologies, and a taste for the study of vernacular languages as a sine qua non for developing a comprehensive and comparative science or even to conduct empirical research. Needless to say these social democratic comparativists were critical of unrestrained capitalism.

Personally I have never considered international and comparative education to be a discipline. I define it as an interdisciplinary quilt, an inter-disciplinary field.

In the sixties and seventies many of the dominant theoretical and methodological developments of the previous generation were criticized, including a critical consideration of rates of return to education studies (true obsession of the generation in the seventies, eighties and even nineties), and a defense of new options like non-formal and popular education, revolutionary education, the emerging multiculturalism, and to put it in one sentence paraphrasing Freire and Ricoeur, an epistemology of suspicion.

The epistemology of suspicion is to always suspect that any social relationship involves instances of domination as taught us by Freire in Pedagogy of the Oppressed , but also Albert Memmi, Franz Fanon, the Black Consciousness Movement with the unique thought of Steve Biko, and of course the essential French philosopher Paul Ricoeur who taught for many years at the University of Chicago.

This generation of critics in comparative education was never very numerous and indeed lived in a growing tension with their siblings, a technocratic generation that grew up under the shadows of institutions of the global system such as the World Bank, OECD, and some specialized units of the United Nations system. Although these institutions certainly did not invent neoliberalism, they helped to shelter it as the hegemonic logic in political economy, politics, and culture and particularly in education.

With the fall of the Berlin Wall neoliberal technocracy won a place in the academies of science and education, becoming the Modelo para Armar, as Cortázar would say. It is a model that favors systematically a movement of privatization and standardized testing with a corollary movement of 'accountability' and the evaluation state. 
This generation of the sixties is about to retire or have already retired at the beginning of the century. Their careers lived straddled two great strains. On the one hand, they believe in a social-democratic ideology based on the welfare state. Thus, this generation became the cultural and educational Pinocchio's 'talking grilo' in comparative education. On the other, since the eighties they experienced a growing technocratic neoliberal ideology, which became hegemonic, and is further enhanced with globalization.

This was a strange ideological cohabitation because apart from social democrats and neoliberals co-existing, the field congregated a myriad of other perspectives including socialists, Marxists, libertarians, critical pedagogues, Feminists of diverse sign, ethnic and race studies scholars, area studies academics, intellectuals linked to the Critical Theory of Society and business-minded scholars.

The first and a half decade of the new century offers to us a very complex picture. Comparative and international education is installed within the academies, especially in the advanced industrial world, but it is not growing in universities. The employment growth in this interdisciplinary field is not in academia but in other institutions, including the global institutional system of bilateral and multilateral institutions, local and regional state management agencies in charge of educational research and planning, transnational social movements, and national and transnational NGOs.

This is no time to make a diagnosis of the crises of civilizations that presents dangerous crossing roads, already anticipated by Gabriel García Márquez (2018) in his speech accepting the Nobel Prize in 1982 when he said:

On a day like today, my master William Faulkner said, "I decline to accept the end of man". I would fall unworthy of standing in this place that was his, if I were not fully aware that the colossal tragedy he refused to recognize thirty-two years ago is now, for the first time since the beginning of humanity, nothing more than a simple scientific possibility. Faced with this awesome reality that must have seemed a mere utopia through all of human time, we, the inventors of tales, who will believe anything, feel entitled to believe that it is not yet too late to engage in the creation of the opposite utopia. A new and sweeping utopia of life, where no one will be able to decide for others how they die, where love will prove true and happiness be possible, and where the races condemned to one hundred years of solitude will have, at last and forever, a second opportunity on earth.

I make mine these words of García Márquez and hope his utopia is a manifest destiny of the utopia of comparative education. But what have we learned over these 100 plus years of comparative education? 
My colleague and friend Robert Arnove said it well in the introduction to our book Comparative Education: The Dialectics of the Global and Local we have learned to work in three broad orientations that complement each other.

First a scientific orientation, that contributed much to the construction of theories and to strengthen the epistemological and scientific methodologies in comparative education. This approach inspired the cross-national education and one of its most obvious implications the studies, creating longitudinal databases that are now called, with the grandiloquence of our professions - Big Data.

There is a second dimension that Arnove called Pragmatic. That is, how can we discover other practices that could apply in our domains? What Phillip Altbach called many years ago 'lending and borrowing'; that is to lend and to borrow educational practices and techniques. This concept is not new, it has thousands of years of existence. Only now we can encapsulate such idea in one of the dimensions of our interdisciplinary melting pot. Along with this comes the idea of' best practices' or good practices which, appropriately contextualized, can be helpful to improve systems in other countries or regions.

Finally there is an international dimension of education; a dimension that is eminently global. The internationalization of educational practices has become the response to globalization and one of its most obvious institutional practices. It is in this dimension of internationalization that one may aspire to build a global consciousness of solidarity and peace.

I would like to believe that this third perspective or orientation, in addition to boosting the trans-nationalization of education, promotes mutual understanding and greater intelligibility between societies, cultures and languages, and can contribute to safeguarding world peace, education for sustainability, and education for global citizenship. This third orientation promotes the development of global awareness and understanding.

Faced with these traditions and learnings, what is the role played by the World Council of Comparative Education Societies?

\section{Comparative and international education and the role of the WCCES}

Considering the evolution of comparative and international education in the last fifty years invites us to ask the following question: how much of this development of comparative and international education has been linked to the history and current status of WCCES?

My working hypothesis is that there is virtually no interpenetration between the history, workings, and development of WCCES and developments taking place in comparative and international education as a discipline of disciplines. If there were to exist some intersectionality as suggested by my UCLA colleague Kimberlé W. Crenshaw in 
understanding the study of analytical categories in the social sciences, unfortunately that intersection between the Council and the discipline in the past would be at best marginal or tenuous.

The foundational question of this comparative analysis of the development of comparative education and the development of the Council should wonder how we may explain why apparently there are parallel developments rather than rich intersections between the work of WCCES and the development of comparative and international education.

Furthermore, if this hypothesis can be proven correct, our central goal with our new leadership should be how can we work towards a new future in which WCCES makes a more pronounced, distinct and original contributions to the development of the discipline that we are supposed to represent, contribute to, and nurture.

The new leadership of Dr. N'Dri Assie Lumumba as President, Dr. Lauren I. Misiaszek, as Secretary General, and Dr. Kanishka Bedi, as Treasurer, have as a team but also individually the brilliant intellectual resources, as well as the cultural, ethnic, racial and gender sensitivities and experience, language diversity, and postcolonial vision to make sure that consistently the WCCES becomes an active player in the expansion with new and higher levels of excellence of international and comparative education in our global world.

In these terms, it will be an essential exercise to ask what are the real contributions of WCCES to member's societies and international comparative education in general and what should be new initiatives in the new stage of institutionalization, democratization, and professionalization of the Council that I have endeavored to promote?

I am convinced that so far the best contributions of comparative and international education have taken place in other neighborhoods and in local contexts, not in the realm of WCCES. My own institution, a true powerhouse in international comparative and international education, provides us with an example.

The remarkable household names contributions of senior professors in the discipline like Tom La Belle studying non-formal education and Latin America education whom I replaced as faculty after he left, John Hawkins studying higher education, internationalization of education and Asian education, Val Rust studying Western and Eastern Europe as well as postmodernism, the late Don Nakanishi comparing Latin American and Asia, and the newer members of our comparative education division, Edith Mukudi Omwami a specialist on African education and Richard Desjardins a specialist on economics of education, Western Europe and non-formal education, while taking comparative and international education in the United States and internationally to new heights, with few exceptions have ever historically participated in WCCES business, meetings and World Congresses, though they have provided a host of Presidents to CIES.

The contributions of comparative and international education has gone through other institutional and national locations, especially in the societies associated with the 
Council demonstrating that the parts may be much more important than the whole. In addition to scholarly and professional societies comparative education developed in universities with courses, doctoral theses, and scientific research, private foundations such as the Ford Foundation or Spencer Foundation, or/and bilateral agencies and multilaterals institutions of the world-system as the World Bank, OECD, Canadian and Scandinavian institutions promoting international aid to education, and the contribution of the United States via USAID.

WCCES has so far a very limited scientific contribution to research and scientific publications, limited impact in the life of the universities and perhaps in the life of the societies that are components of the Council. This represents a practically null impact in the constructions of global public policies in education, and limited exposure if any presence in the UN institutions, particularly Unesco despite being an Unesco Associated NGO.

\section{New actors, new concepts new challenges: quo vadis?}

Let me conclude with some proposals of where to go from here.

WCCES should endorse and adopt the positions advanced in the World Education Forum that took place in Incheon, Republic of Korea, 19-22 May 2015. The Forum was entitled Equitable and inclusive quality education and lifelong learning for all by 2030. Transforming lives through education. The majority of these positions were adopted by the the Assembly of the UN in September 2015.

We shall assume our commitment remains firm for equity transformational projects aimed at disrupting inequality (i.e. promoting analyses following Amartya Sen's capability approach or the many recommendations emanating from Thomas Piketty in Capital in the Twenty First Century).

Please pay special attention to the proposal of Laudato Si' (Praise be to you-On Care for our Common Home) pronounced by Pope Francis in defense of the environment. In this spirit, WCCES should adopt the paradigm of eco-pedagogy related to the work of Critical Pedagogues, and the concept of educational for sustainable development as a framework for action in protecting the environment.

Understand the transformations of multi-polarity in the World System in the context of a new model of globalization where immigration becomes a transformative character of social realities.

Please also pay due attention to the new narratives that are emerging in the context of the global system to challenge hegemonic narratives, especially the powers of the idea of global citizenship education.

In the context of the current crisis of humanity, it is imperative that the WCCES fosters a comprehensive conversation about education for peace at WCCES. Let me 
go back to the Manifest for Peace that I wrote after the events in January of 2015 in France and is the foundational document of the WCCES Peace Education Task Force under the Chairships of Professors Lynette Schultz and Kanishka Bedi.

The UN Assembly in 2015 formulated a consensus built by all nations of the globe. As a Unesco associated NGO, we need to relate more closely our work to UN models of peace education, education for sustainable development and global citizenship education, recognizing the importance of the 2030 Sustainable Development Agenda with 17 goals and 169 targets and implementing its symbolic five dimensions including people, planet, prosperity, peace and partnership.

Therefore, I propose to the WCCES to begin the great conversation about education for peace in the context of the 2030 Sustainable Development Agenda. To carry out this conversation I hope we may reach out to our societies and our modest international structure as well as our Standing Committees bringing our work more closely aligned to the politics of U.N. and Unesco. What follow are some key principles for discussion.

First, we must not resort to repeating failures of the past. We must use this opportunity for a better world with alternative approaches to conflict resolution and peace. Though war might sometimes be inevitable (it is after all one of the responsibilities of the Nation-States as defined by Western political philosophy), we must organize against and stop the perpetual visions of foreign policy and economies that thrive on war. We must pressure governments to seek political and diplomatic solutions to global problems. But if ideologies like Nazism and Fascism cannot be persuaded to give up their global ambitions, the world democracies should organize a reasonable response avoiding as much as possible civilian casualties.

Second, we must support and guide the building of global solidarity movements that are founded on premises that counter racism, Islamophobia and extremist ideologies. Groups need to be established to educate communities about mutual respect, empathy, various privileges, histories of marginalized groups, and community and socially responsible entrepreneurship.

Third, we should host a World Social Forum conference in North Africa and Southwest Asia that brings together various religious scholars, civil society organizations, youth leaders and activists, and other people to address and organically and inclusively create new peaceful ideologies and social policies that resonate with indigenous structures and beliefs that challenge violence.

Fourth, pressure all governments and the U.N. to prosecute war crimes for those responsible for atrocities on all sides of the political spectrum.

Fifth, support and build spaces for disenfranchised and marginalized youth throughout the world to listen to their grievances, empower them to participate in society, provide tools for conflict resolution, and have them contributing to addressing social issues. Make sure that we use the power of reason and education to prevent further 
radicalization of youth following extremist religious and nationalistic perspectives giving meaning to lives that find no meaning otherwise. But most important, intense conversations about violent interpretations of Islam should take place through the world, conducted by Islamic scholars who should answer these radical interpretations responsible as well for the internecine wars between Islamic faith groups.

Sixth, counter governments' adoption of neoliberal based policies to seek out economic alternatives that are more inclusive and less socially and environmentally destructive.

Seventh, to convey to Unesco that they need to double its efforts to bring dialogue about conflict and peace in the world system inside our governments, community organizations, social movements, political parties, and world citizens. WCCES needs to feature in our mass media more dialogue about peace, global citizenship, and education for sustainable development. We should offer our services to promote peace at any cost. Only this way we may be able to promote life, liberty and the pursuit of happiness. Peace is a treasure of humanity and we should preserve it at any cost.

Eight, to seek these goals, we should immediately begin an institutional conversation among ourselves of how we can help in the promotion of world peace.

Nine, as members of the WCCES community, it is our duty to help educators complicate their understanding of diversity, and subsequently create a more inclusive learning environment for all students. Helping educators to expand student perspectives toward a more global and interconnected framework, which is essential in deconstructing the marginalizing discourses that often permeate our educational institutions.

There are two sources of legitimacy of WCCES and they may be their most fundamental contributions to the multiple specialties of the field of international comparative education: The organization every three years of a World Congress of Comparative Education, and our association as NGO to Unesco.

To strengthen our legitimacy and become better related to the developments in comparative and international education, WCCES should be linked more intimately to the transformations of educational policies in the international system, particularly playing a major and serious role in the The Sustainable Development Goals which are a UN Initiative. A more active and vital association with Unesco will certainly facilitate the actions of WCCES in this domain.

Let me repeat that the most important contribution of the Council to comparative and international education is the organization every three years a World Congress of Comparative Education.

After the XVI World Congress of Comparative Education in Beijing, and in the new World Congress that will take place in Cancun, Mexico, we hope the changes that were promoted under my administration seeking institutionalization, professionalization, transparence and democratic deliberation and evaluations will continue and 
strengthen. Of particular importance is the role of the Bureau that was authorized by the Executive Committee to be reactivated after been inoperable for 15 years, will help in answering the question that marks this keynote: What are the contributions of the WCCES to an interdisciplinary field such as comparative and international education How the WCCES could contribute to comparative and international education in a more effective, transformative, as well as more intellectually ethical and professional form? What should be the role of WCCES in addressing multifaceted global problems that the world is currently facing ${ }^{2}$ ?

Thank you very much for your attention.

\section{Notes:}

1 Keynote for the XVI World Congress of Comparative Education, Beijing, August 2016.

2 I am thankful to Dr. Greg Misiaszek, Dr. Jason Dorio, Jiang Jia, and Dr. Robert Arnove for their valuable comments to a previous version.

\section{References:}

Cabral, A. (2018). The weapon of theory: address delivered to the first Tricontinental Conference of the Peoples of Asia, Africa and Latin America held in Havana in January, 1966. Disponivel em: www. marxists.org/subject/africa/cabral/1966/weapon-theory.htm . Acesso em: 18 set. 2018.

Domingo Sarmiento, F. (2010 [1849]). Popular education. Charleston, SC, US, Nabu.

Freire, P. (2010). Pedagogy of the oppressed. 30th anniversary edition. New York: Continuum.

García Márquez, G. (2018). The solitude of Latin America: Nobel lecture, 8 December, 1982. Disponível em: www.nobelprize.ofg/prizes/literature/1982/marquez/lecture/. Acesso em: 18 set. 2018.

Carlos Alberto Torres

Past President of the World Council of Comparative Education Societies. Is Distinguished Professor of Education and UNESCO- UCLA Chair in Global Learning and Global Citizenship Education.

E- mail: catnovoa@aol.com ORCID: https://orcid.org/0000-0003-2753-331X

Correspondência

Carlos Alberto Torres

Campo Grande, 376 1749-024 Lisboa

Data de submissão: Setembro 2017

Data de avaliação: Outubro 2017 Data de publicação: Setembro 2018 